CATALLAXY

Volume 4 Issue 1 June 2019

e-ISSN 2544-090X

$\triangle$ www.catallaxy.pl

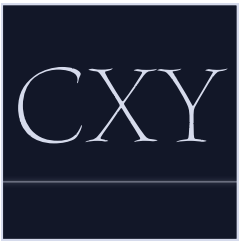

Oryginalny artykut naukowy

otrzymano: 04.06.2019 / zaakceptowano: 28.06.2019 / opublikowano online: 30.06 .2019

Mierzejewski, M. (2019). Wspólnoty nierówności: cechy spoteczeństw z wysokim zróżnicowaniem dochodowym. Catallaxy, 4(1): 13-27. doi:10.24136/cxy.2019.001.

\title{
Wspólnoty nierówności: cechy społeczeństw z wysokim zróżnicowaniem dochodowym
}

\section{MATEUSZ MIERZEJEWSKI}

Uniwersytet Ekonomiczny w Krakowie, Wydział Ekonomii i Stosunków Międzynarodowych, Katedra Rozwoju Organizacji, ul. Rakowicka 27, 31-510 Kraków, Polska

వmierzejm@uek.krakow.pl

(D) orcid.org/0000-0001-8542-2373

\section{Abstrakt}

Motywacja: Kwestia nierówności dochodowych znajduje się obecnie w centrum debaty publicznej. W ostatnich latach można dostrzec nasilenie się zjawiska dysproporcji dochodowych, choć nie we wszystkich państwach. Jego następstwem jest pogarszająca się kondycja społeczna, rozumiana jako zachowania społecznie niepożądane.

Cel: Celem jest próba ujęcia cech, które pojawiają się wraz ze wzrostem nierówności dochodowych w społeczeństwie. Materiały i metody: Wykorzystano dane pochodzące z różnych źródeł: Organizacji Współpracy Gospodarczej i Rozwoju (Organisation for Economic Co-operation and Development, OECD), Banku Światowego (World Bank) oraz Swiatowej Organizacji Zdrowia (World Health Organization, WHO). Zakres czadowy obejmuje lata 1960-2017. Posłużono się metodą opisowa, jak również wybranymi metodami ilościowymi: wskaźnikiem korelacji, metodą dendrogramu Warda oraz analizą spektralną, wykorzystywaną do oceny cykliczności zjawisk ekonomicznych.

Wyniki: Na podstawie przeprowadzonej analizy można dostrzec podwyższony i bardziej niestabilny poziomu bezrobocia w państwach o wyższym zróżnicowaniu dochodowym.

Stowa kluczowe: nierówności dochodowe; bezrobocie; ubóstwo JEL: D63; D69

\section{Wprowadzenie}

„Transfer 1 funta od osoby bogatej do osoby o gorszym statusie materialnym, przy zachowaniu wszystkich innych zmiennych, zmniejszyłby nierówność i zmniejszył sumę korzyści społeczeństwa jako całości” twierdził H. Dalton, kanclerz skarbu oraz brytyjski ekonomista. Opinia ta wyraźnie wskazuje na konieczność rozpatrywania zjawiska nierówności dochodowej oraz majątkowej w rozwoju współczesnych społeczeństw.
Niwelowanie różnic wynikających z czynników zewnętrznych (nierówności szans), w odpowiednich warunkach daje możliwość maksymalizowania efektywności pracy całego społeczeństwa. W najnowszych pracach ekonomicznych czynniki wpływające na ekonomiczne wyniki jednostek dzieli się na te, które są zastane przez poszczególne jednostki, np. rodzaj środowiska rodzinnego (czynniki zewnętrzne) oraz te, które wynikają z aktywności samych jednostek, a więc wysiłku pracy, dzięki któremu jednostka osiąga wybrane 
przez siebie cele (czynniki wewnętrzne) (Romer, 1998).

Zjawisko nierówności należy do obszaru idei rozwoju społecznego, która powstała na gruncie modyfikacji teorii wzrostu gospodarczego. Polega ona na traktowaniu rozwoju gospodarczego jako środka do budowania dobrostanu społecznego. Wszelkie działania w obszarze tej idei zaczęto nazywać działaniami dobrego rozwoju (good development) lub rozwoju społecznego skupionego na człowieku (human-centered social development) (Księżopolski, 1995, s. 28). Wśród przyczyn występowania nierówności najczęściej wskazuje się: globalizację, postęp technologiczny, zawodność instytucji rynku pracy, nieefektywność systemów podatkowych oraz deregulację sektora finansowego (Brzeziński, 2017, s. 3).

Warto przedstawić zagrożenia wynikające $z$ lekceważenia polityki rozwoju społecznego, które są obecnie rozpatrywane $\mathrm{w}$ naukach ekonomicznych, tworząc tym samym opis cech niepożądanych, które pojawiają się w społeczeństwach o wyższych nierównościach dochodowych.

Celem pracy jest przedstawienie cech społecznych, charakterystycznych dla państw, w których występują istotnie nierówności dochodowe i majątkowe.

W sekcji 2. opisano wykorzystane materiały i metody. W sekcji 3. scharakteryzowano problem nierówności w skali globalnej. W sekcji 4. przedstawiono cechy nierówności w państwach wysokorozwiniętych. W sekcji 5. zawarto podsumowanie przeprowadzonej analizy.

\section{Materiały i metody}

Zakres przedmiotowy obejmuje następujące wskaźniki ekonomiczne: wartość PKB per capita, wskaźnik Giniego, wskaźnik ubóstwa, udział wydatków socjalnych w PKB, stopa bezrobocia, udział palaczy $w$ ogóle społeczeństwa oraz poziom konsumpcji alkoholu. Zakres czasowy obejmuje lata 1960-2017, natomiast długość szeregów czasowych została podyktowana dostępnością danych. Wykorzystano dane pochodzące $z$ różnych źródeł: Organizacji Współpracy Gospodarczej i Rozwoju (Organisation for Economic Co-operation and Development, OECD, 2019), Banku Światowego (World Bank, 2019) oraz Światowej Organizacji Zdrowia (World Health Organization, WHO, 2019). Posłużono się metodą opisową, jak również wybranymi metodami ilościowymi: wskaźnikiem korelacji, metodą dendrogramu Warda oraz analizą spektralną wykorzystywaną do oceny cykliczności zjawisk ekonomicznych (Mierzejewski, 2018).

\section{Problem nierówności globalnej}

Ograniczanie nierówności w gospodarce światowej argumentowane jest koniecznością wyrównywania szans przyszłych pokoleń (Atkinson, 2017; Wilkinson i Pickett, 2011). Wynika także $z$ innych, szeroko omawianych $\mathrm{w}$ literaturze przedmiotu, instrumentalnych powodów, do których zalicza się: brak spójności społecznej, wzrost przestępczości, zapadalność na choroby, wzrost odsetka ciąż u nastolatek oraz problem otyłości (Stiglitz, 2015). Ponadto, wskazuje się, że dysproporcja dochodowa odnajduje swoje przełożenie w wynikach demokratycznych wyborów (McCarty i in., 2006). Co więcej, występujące w społeczeństwie nierówności $w$ znaczącym stopniu wpływają na makroekonomiczną stabilność gospodarki - mniejszy poziom nierówności przekłada się na bardzie stabilny i zrównoważony wzrost gospodarczy (Lagarde za Atkinson, 2017).

Przejawy nierówności mogą być różne: dostęp społeczeństwa do dóbr i usług kulturowych, ekonomicznych, władzy, prestiżu, opieki zdrowotnej, edukacji (Szopa, 2012). W naukach ekonomicznych przedmiotem zróżnicowania społecznego są w szczególności majątek i dochód poszczególnych społeczeństw. Właśnie tę kategorię zróżnicowania, jako jedną $z$ najistotniejszych cech społeczeństwa, wskazywał M. Weber (2002). Sumarycznym wskaźnikiem pozwalającym na zobrazowanie nierówności globalnych jest Produkt Krajowy Brutto przypadający na jednego mieszkańca. Oczywiście, analizując takie zróżnicowanie trzeba pamiętać, że daje 
ono jedynie zarys opisu zjawiska ze względu na wewnętrzne, strukturalne różnice $\mathrm{w}$ rozwoju poszczególnych państw (Szopa, 2012).

$\mathrm{Na}$ wykresie 1. przedstawiono kształtowanie się zmian PKB per capita w czterech grupach państw sklasyfikowanych według norm Atlasu Banku Światowego. Na ich podstawie można podzielić wszystkie 218 państw na cztery grupy pod względem poziomu dochodu: niskiego, średniego-niskiego, średniego-wysokiego oraz wysokiego. W 2019 roku graniczny poziom dochodu był następujący (World Bank, 2019):

- niski dochód: PKB per capita na poziomie 995 USD lub mniej;

- niski-średni dochód: PKB per capita w przedziale 996-3 895 USD;

- średni-wysoki dochód: PKB per capita w przedziale 3 896-12 055 USD;

- wysoki dochód: PKB per capita na poziomie 12056 USD lub więcej.

$\mathrm{Na}$ podstawie danych zaprezentowanych na wykresie 1. można wyciągnąć wniosek, że w grupie państw najbogatszych nie odnotowano $\mathrm{w}$ analizowanych latach wyższego, zagregowanego wzrostu gospodarczego. Może to wskazywać na proces doganiania przez pozostałe gospodarki. Niemniej, najniższy wzrost gospodarczy zaobserwowano w państwach najbiedniejszych, co natomiast wskazuje na pogłębiający się problem narastania globalnych nierówności dochodowych.

Warto podkreślić cechę charakterystyczną dla gospodarek słabiej rozwiniętych, które charakteryzują się niższym wpływem długookresowych wahań koniunkturalnych. $\mathrm{Na}$ wykresie 2. przedstawiono kształtowanie się wielkości gęstości spektralnych zmian PKB per capita, które opisują wkład poszczególnych, występujących cykli na kształtowanie się zmiennej. W przypadku państw o średnich dochodach, zmiana ta była zdeterminowana przez wahania trzydziestoletnie. Natomiast w przypadku państw wysokorozwiniętych dziewięcioletnie. W odniesieniu do regionów o niskich dochodach, wkład ten rozkładał się na pięć cykli czasowych.
4. Cechy nierówności w państwach wysokorozwiniętych

Jak wspomniano, nierówności mogą charakteryzować się odmiennymi cechami wynikającymi bezpośrednio $z$ wewnętrznej struktury gospodarki danego państwa. W kolejnym etapie analizy, wyodrębniono pięćdziesiąt osiem państw wysokorozwiniętych.

$\mathrm{Na}$ wykresie 3. przedstawiono podział państw na dwie grupy o odmiennych poziomach nierówności, które mierzone były wskaźnikiem Giniego. Różnice te wynoszą około 8 p.p. i mogą być uznane za wątpliwe, w zależności od obserwatora. $\mathrm{Na}$ tej podstawie wyznaczono dwie grupy państw. W skład pierwszej grupy charakteryzującej się niskim poziomem nierówności wchodzą następujące państwa: Austria, Belgia, Czechy, Dania, Finlandia, Francja, Holandia, Irlandia, Islandia, Niemcy, Norwegia, Polska, Słowacja, Słowenia, Szwajcaria oraz Szwecja. Do drugiej grupy, charakteryzującej się wysokim poziomem nierówności przyporządkowano następujące państwa: Chorwacja, Estonia, Grecja, Hiszpania, Kanada, Litwa, Łotwa, Meksyk, Portugalia, Stany Zjednoczone, Turcja, Wielka Brytania oraz Włochy.

$\mathrm{Na}$ wykresie 4. przedstawiono kształtowanie się zmian $\mathrm{w}$ poziomie nierówności w wybranych grupach państw. W przypadku pierwszej grupy ( $z$ wyjątkiem Finlandii) odnotowano spadkową tendencję poziomu nierówności. W grupie drugiej poziom ten był zbliżony i wahał się w granicach 0,30-0,48.

Jednym $z$ najważniejszych argumentów przemawiających za utrzymywaniem wysokiego poziomu nierówności jest teoria skapywania, według której wzrost bogactwa zamożnych podmiotów mikroekonomicznych przynosi korzyści także ubogim podmiotom.

Mimo optymistycznych rozstrzygnięć koncepcji skapywania, doświadczenia wielu państw rozwijających się wskazywały, że strategie rozwoju opierające się na tej koncepcji okazały się dużo mniej skuteczne niż zakładano. Jak przedstawiono na wykresie 5. poziom ubóstwa mierzonego jako stosunek liczby osób, których dochód spada poniżej 
granicy ubóstwa (przyjęto ją jako połowę mediany dochodu gospodarstwa domowego całej populacji), jest zdecydowanie niższy w państwach o niższym poziomie nierówności dochodowych. Nie jest to jednak spostrzeżenie zaskakujące, gdyż wynika $z$ faktu, że rozkład dochodu w państwach o wyższym poziomie nierówności jest prawostronnie skośny. Warto podkreślić fakt, że system podatkowy, nakierowany na redystrybucję społeczną, zakłada transfer środków właśnie do ubogich warstw społeczeństwa.

W kontekście przyśpieszonego rozwoju gospodarczego warto zaznaczyć rolę, jaką odegrał promowany w latach 90. XX wieku neoliberalizm (Mierzejewski, 2015). W rezultacie, w gospodarce dominowały poglądy wolnorynkowe zakładające: twardą politykę fiskalną i monetarną, deregulację i liberalizację przepływów handlowych, ograniczenie opodatkowania oraz zmniejszanie poziomu transferów społecznych (Wojtyna, 2007).

W Wielkiej Brytanii gwałtowny wzrost nierówności $w$ drugiej połowie lat 80 . był zbieżny z wyraźnymi reedukacjami świadczeń socjalnych. Wdrożone ograniczenie emerytury w stosunku do średniej płacy, zwiększyło występującą lukę dochodową między seniorami otrzymującymi świadczenia prywatne a tymi, którzy otrzymywali jedynie emeryturę państwową (Atkinson, 1993). Zgodnie $z$ raportem Handbook of income distribution, $\mathrm{w}$ gospodarkach rozwiniętych nie odnotowano niskiego poziomu nierówności przy niskim poziomie wydatków społecznych (Marx $\mathrm{i}$ in., 2015).

Jak zobrazowano na wykresie 6., poziom wydatków socjalnych w odniesieniu do PKB był zróżnicowany $\mathrm{w}$ odniesieniu do poziomu wskaźnika nierówności społecznych. Mediana wysokości wydatków socjalnych w grupie o niższych wartościach wskaźnika nierówności wynosiła około $23 \%$ i była wyższa o około 5 p.p. w porównaniu do drugiej grupy. Warto jednak zaznaczyć, że samo wprowadzanie świadczeń społecznych nie jest wystarczającym narzędziem wpływającym na zwalczanie nierówności. Obecnie wiele państw, dokonując zmian w zakresie świadczeń społecznych, wykorzystuje zabezpieczenia w postaci kryterium dochodowego, które ma za zadanie ograniczać błędy w wypłatach nieuzasadnionych (a więc takich, które stanowią próbę wykorzystania systemu polityki państwa przez konsumenta). Tym samym wpływa się na skuteczność narzędzi wsparcia społecznego, co w konsekwencji przyczynia się do zwiększania nierówności (Atkinson, 2017).

Kolejną cechą, przedstawioną na wykresie 7., jest różny poziom stopy bezrobocia względem nierówności. Wartość średnia w przypadku pierwszej grupy wynosiła 7,18\%, zaś w przypadku drugiej grupy - aż $10,00 \%$. Ponadto, grupa o wyższym poziomie nierówności charakteryzowała się zdecydowanie wyższym poziomem odchylenia standardowego, które wynosiło 5,09. Wskazuje to, że państwa o wyższym poziomie nierówności charakteryzować się będą również wyższym poziomem bezrobocia wyróżniającym się zdecydowanie większym spektrum zmienności, niż w przypadku państw o niższym poziomie nierówności.

Co więcej, jak przedstawiono na wykresie 8., cecha ta (wyższy poziom i zmienność bezrobocia przy większym poziomie nierówności) występuje również $\mathrm{w}$ przypadku zmian $\mathrm{w}$ czasie. Na podstawie wykresu 8. można uznać, że średni poziom stopy bezrobocia w pierwszej grupie w latach 2002-2017 był niższy niż 5\%. Oba szeregi wykazują zmienność koniunkturalną, jednak $\mathrm{w}$ przypadku drugiej grupy można zaobserwować, że wartości średnie były zdecydowanie wyższe. Ponadto, grupa ta charakteryzowała się większymi odchyleniami.

$\mathrm{Na}$ wykresie 9. przedstawiono zróżnicowanie transferów budżetowych w wybranych grupach państw. Państwa o wyższym poziomie nierówności charakteryzowały się niższym poziomem transferów społecznych. Średnia wartość wydatków socjalnych dla bezrobotnych (jako odsetek PKB) wynosiła $\mathrm{w}$ tej grupie $0,85 \%$ (w porównaniu do $1,23 \%$ $\mathrm{w}$ pierwszej grupie). Natomiast średnie transfery środków do gospodarstw domowych wynosiły 19\% PKB (w porównaniu do $23 \%$ w pierwszej grupie). 
Ostatnią obserwowaną cechą był udział palaczy $\mathrm{w}$ ogóle społeczeństwa oraz poziom konsumpcji alkoholu $\mathrm{w}$ analizowanych państwach. W zaproponowanym podziale na dwie grupy państw nie zaobserwowano jednak wyraźnych różnic ze względu na poziom wartości wskaźnika Giniego. Na wykresie 10. przedstawiono ujęcie ogólne. W przypadku pierwszej grupy, średni udział palaczy i poziom konsumpcji alkoholu wynosił odpowiednio 10\% i 201 per capita, zaś dla drugiej grupy odpowiednio: 9\% i 211 per capita.

\section{Zakończenie}

Jeden $z$ najskuteczniejszych inwestorów oraz trzeci najbogatszy człowiek na świecie według Forbes (2018)), Warren Buffet, w obliczu cieć podatków progresywnych w Stanach Zjednoczonych miał powiedzieć „Owszem, wojna klas trwa, ale toczy ją moja klasa, bogaczy. I wygrywamy" (Bauman, 2012). Kryzys pierwszej dekady XXI wieku pokazał, że postępująca liberalizacja (Mierzejewski, 2015) oraz nieefektywny system podatkowy wpływają niekorzystnie na społeczną jakość życia. Poszczególne państwa powinny wykorzystywać dostępne narzędzia do łagodzenia działań czynników wpływających na nierówności, w tym transfery społeczne oraz system podatkowy. W artykule poddano analizie zjawiska towarzyszące nierównościom społecznym. Wśród najważniejszych cech społeczeństw o wyższym rozwarstwieniu społecznym należy wymienić:

- większy poziom ubóstwa,

- wyższy poziom bezrobocia oraz większą zmienność zatrudnienia,

- mniej redystrybucyjną politykę socjalną państwa.

Nierówności między obywatelami tych samych państw pogłębiają się prowadząc do pogarszania się jakości życia mieszkańców. Warto jednak podkreślić, że rządy poszczególnych państw nie są jedynie biernymi aktorami na scenie światowych zmian, lecz są w stanie reagować na zmieniającą się rzeczywistość.

\section{Bibliografia}

Atkinson, A.B. (1993). What is happening to the distribution of income in the UK? Proceedings of the British Academy, 82.

Atkinson, A.B. (2017). Nierówności: co da się zrobić? Warszawa: Krytyka Polityczna.

Bauman, Z. (2012). To nie jest dziennik. Kraków: Wydawnictwo Literackie.

Brzeziński, M. (2017). Nierówności dochodowe i majątkowe w Europie: fakty, przyczyny, konsekwencje. W: J. Kleer, i K. Prandecki (red.), Zróżnicowanie dochodowe $i$ społeczne Europy. Warszawa: PAN.

Forbes. (2018). Najbogatsi ludzie świata 2018. Pobrane 29.04.2019 z https://www.forbes.pl.

Księżopolski, M. (1995). Pojęcie rozwoju społecznego. Różne koncepcje postępu społecznego i regresu a idea "rozwoju społecznego". W: Raport o Rozwoju Spotecznym: Polska, UNDP.

Marx, I., Nolan, B., i Olivier, J. (2015). The welfare state and anti-poverty policy in rich countries. W: A.B. Atkinson, i F. Bourguignon (red.), Handbook of income distribution. Amsterdam: Elsevier. doi:10.1016/ b978-0-444-59429-7.00024-8.

McCarty, N., Poole, K.T., i Rosenthal, H. (2006). Polarized America: the dance of ideology and unequal riches. Cambridge: MIT Press.

Mierzejewski, M. (2015). Interwencjonizm na liberalnych rynkach. $\mathrm{O}$ zmianach $\mathrm{w}$ spojrzeniu na gospodarkę $\mathrm{w}$ reakcji na kryzys pierwszej dekady XXI wieku. Rynek, Społeczeństwo, Kultura, 14(2).

Mierzejewski, M. (2018). Wykorzystanie analizy cross-spektralnej do badania zmian wartości indeksów giełdowych. Problems of Economics and Law, 1(1).

OECD. (2019). Pobrane 08.05.2019 z https://data. oecd.org.

Romer, J. (1998). Equality of opportunity. Cambridge: Harvard University Press.

Stiglitz, J. (2015). Cena nierówności: w jaki sposób dzisiejsze podziały spoteczne zagrażaja naszej przysztości? Warszawa: Wydawnictwo Krytyki Politycznej.

Szopa, B. (red.). (2012). Wokót zagadnień ubóstwa ibogactwa. Kraków: UE w Krakowie.

Weber, M. (2002). Gospodarka i spoteczeństwo: zarys socjologii rozumiejacej. Warszawa: PWN.

WHO. (2019). Pobrane 08.05.2019 z https://www. who.int.

Wilkinson, R., i Pickett, K. (2011). Duch nierówności: tam gdzie panuje równość, wszystkim żyje się lepiej. Warszawa: Czarna Owca. 
Wojtyna, A. (2007). Teoretyczny wymiar zależności między zmianami instytucjonalnymi, polityką ekonomiczną a wzrostem gospodarczym. Gospodarka Narodowa, 216(5-6). doi:10.33119/ gn/101367.

World Bank. (2019). Pobrane 08.05.2019 z https:// data.worldbank.org.
Informacje uzupetniające

Wkład autorski: autor zaakceptował ostateczną wersję artykułu.

Źródła finansowania: artykuł został w całości sfinansowany ze środków własnych autora.

Uwagi: wyniki badania były zaprezentowane na 9. Ogólnopolskiej Konferencji Naukowej Problemy gospodarki światowej (10 maja 2019, Toruń). 


\section{Aneks}

Wykres 1.

Stopa wzrostu PKB per capita w czterech grupach państw w latach 1961-2017 (w \%)
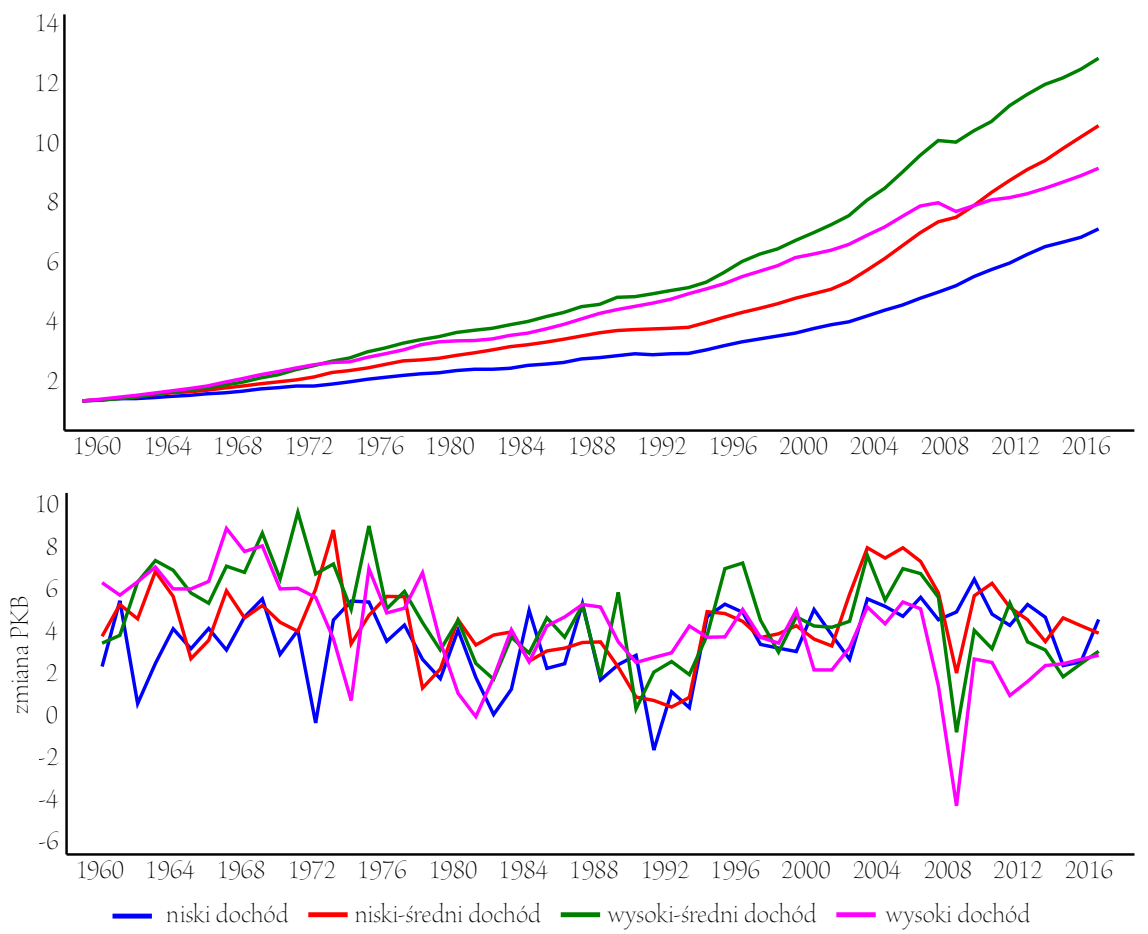

Źródło: Opracowanie własne na podstawie World Bank (2019). 
Wykres 2.

Periodogram gęstości spektralnych zmian PKB per capita w czterech grupach państw

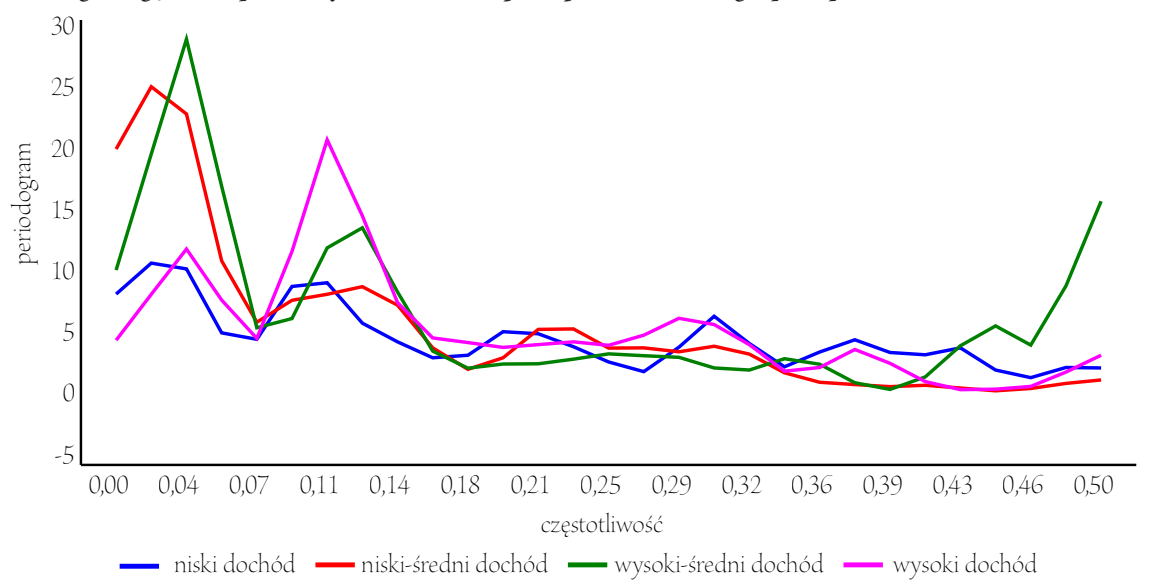

Źródło: Opracowanie własne na podstawie World Bank (2019).

Wykres 3.

Dendrogram podziału państw wysokorozwiniętych ze względu na wielkość nierówności

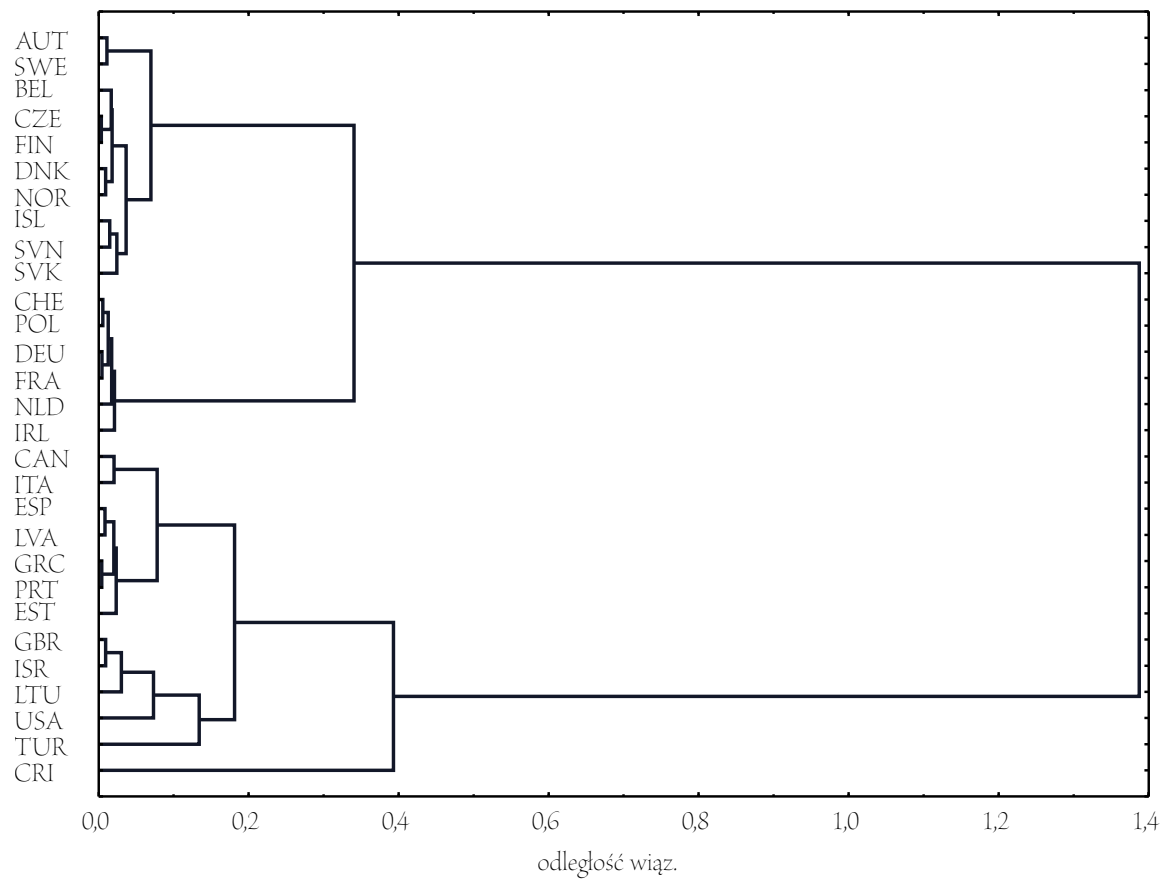

Uwagi:

AUT - Austria, BEL - Belgia, CAN - Kanada, CHE - Szwajcaria, CRI - Chorwacja, CZE - Czechy, DEU - Niemcy, DNK - Dania, ESP - Hiszpa-nia, EST - Estonia, FIN - Finlandia, FRA - Francja, GBR - Wielka Bryta-nia, GRC Grecja, IRL - Irlandia, ISL - Islandia, ISR - Meksyk, ITA - Włochy, LTU - Litwa, LVA - Łotwa, NLD - Holandia, 
NOR - Norwegia, POL - Polska, PRT - Portugalia, SVK - Słowacja, SVN - Stowenia, SWE - Szwecja, TUR - Turcja, USA - Stany Zjednoczone.

Źródło: Opracowanie własne na podstawie World Bank (2019).

Wykres 4.

Poziom wskaźnika Giniego w wybranych grupach państw w latach 1976-2017
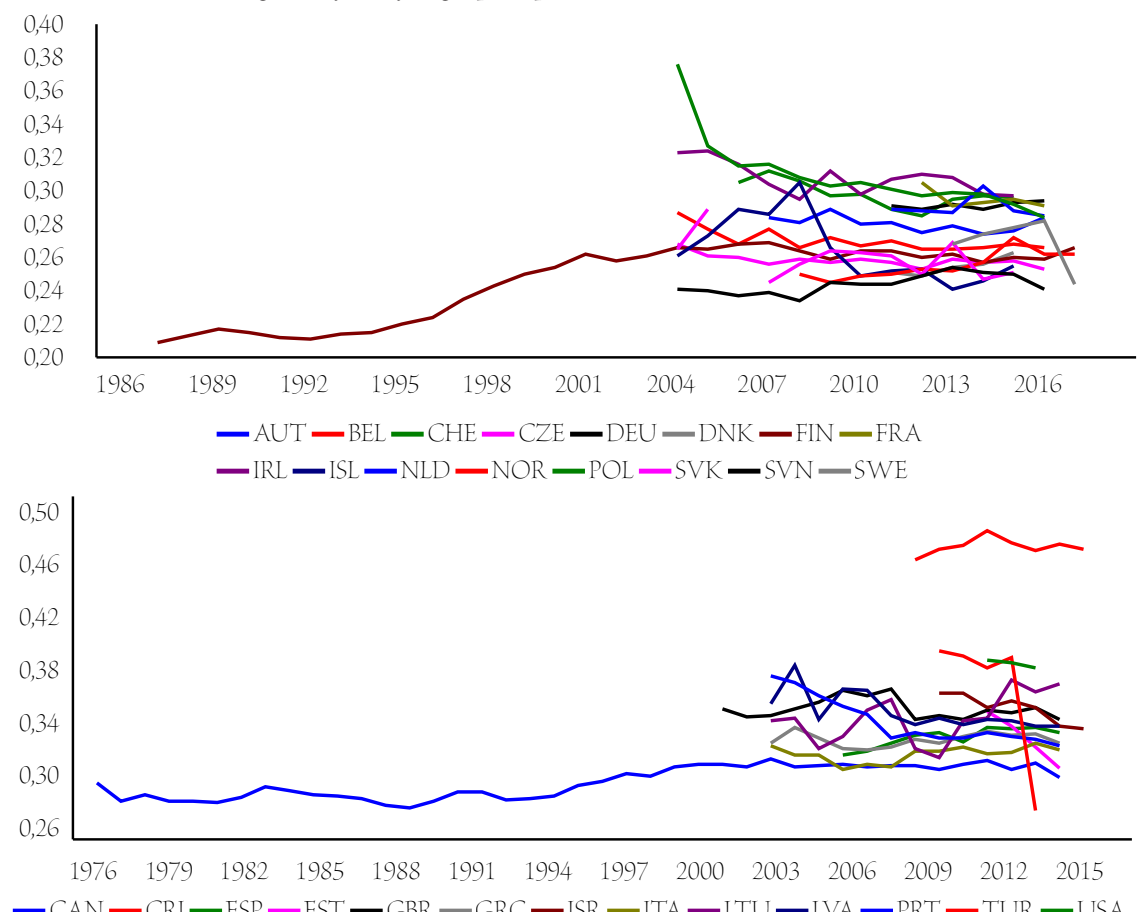

Uwagi:

Oznaczenia jak na wykresie 3.

Źródło: Opracowanie własne na podstawie World Bank (2019). 
Wykres 5.

Ubóstwo względem nierówności społecznych w dwóch grupach państw
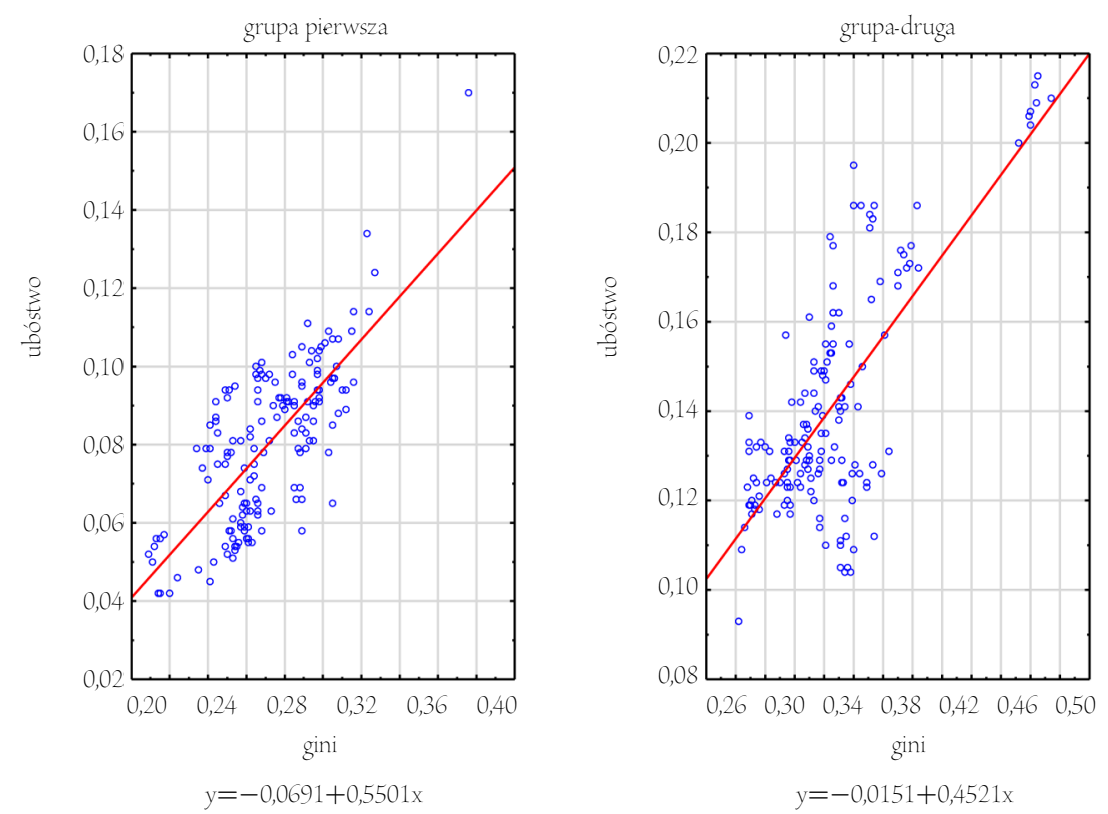

Źródło: Opracowanie własne na podstawie World Bank (2019). 
Wykres 6.

Wydatki socjalne względem nierówności społecznych w dwóch grupach państw
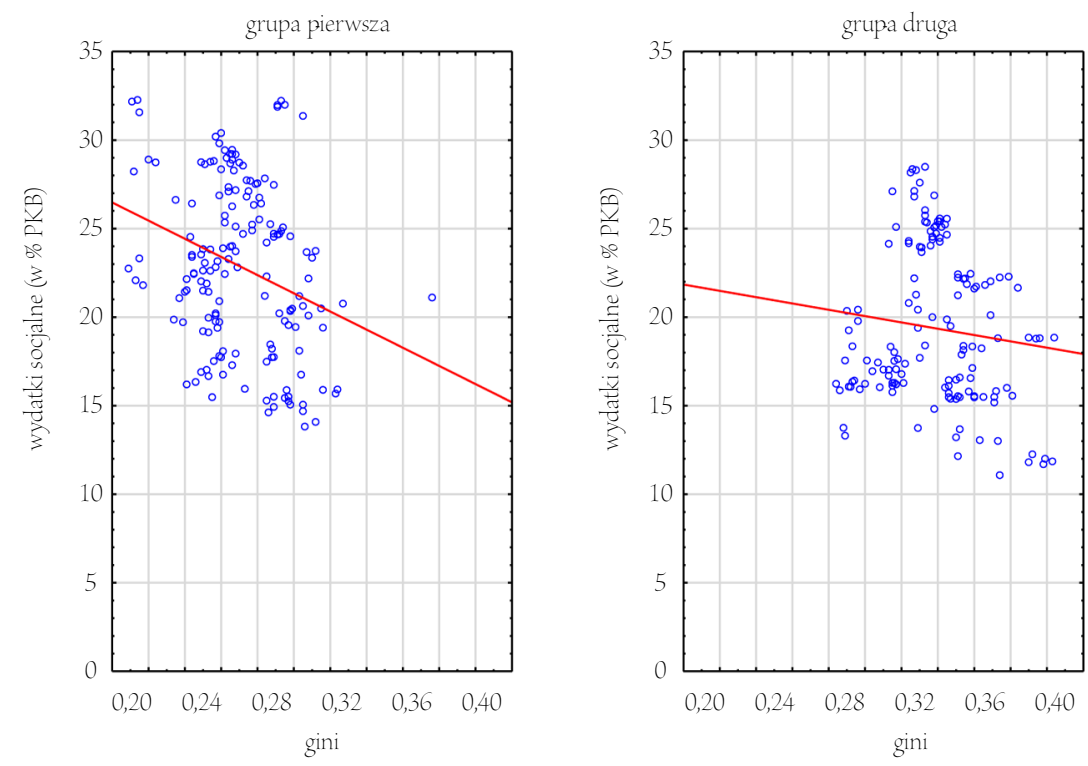

Źródło: Opracowanie własne na podstawie World Bank (2019). 
Wykres 7.

Stopa bezrobocia względem nierówności społecznych w dwóch grupach państw

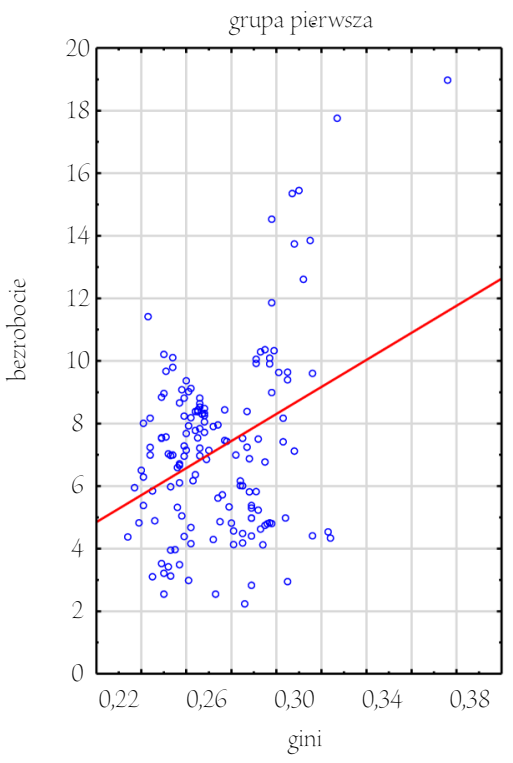

$y=-4,6734+43,2641 x$

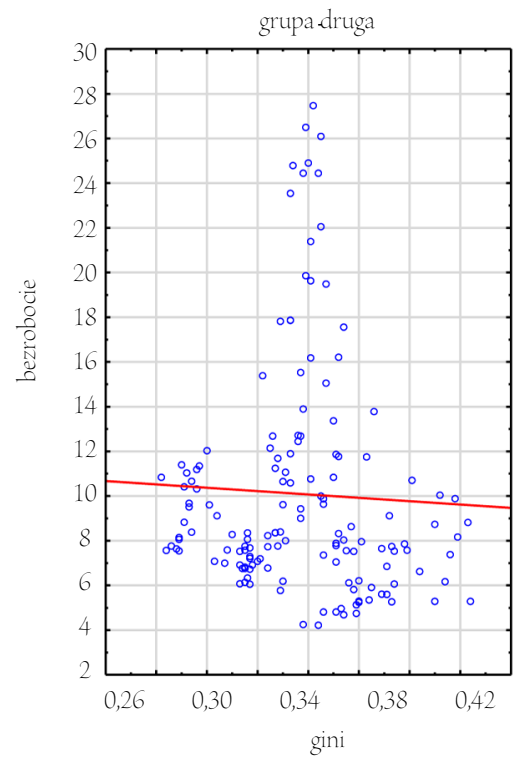

$y=12,6335-7,5333 x$

Źródło: Opracowanie własne na podstawie World Bank (2019). 
Wykres 8.

Zmiany stopy bezrobocia w dwóch grupach państw w latach 1976-2017

grupa pierwsza
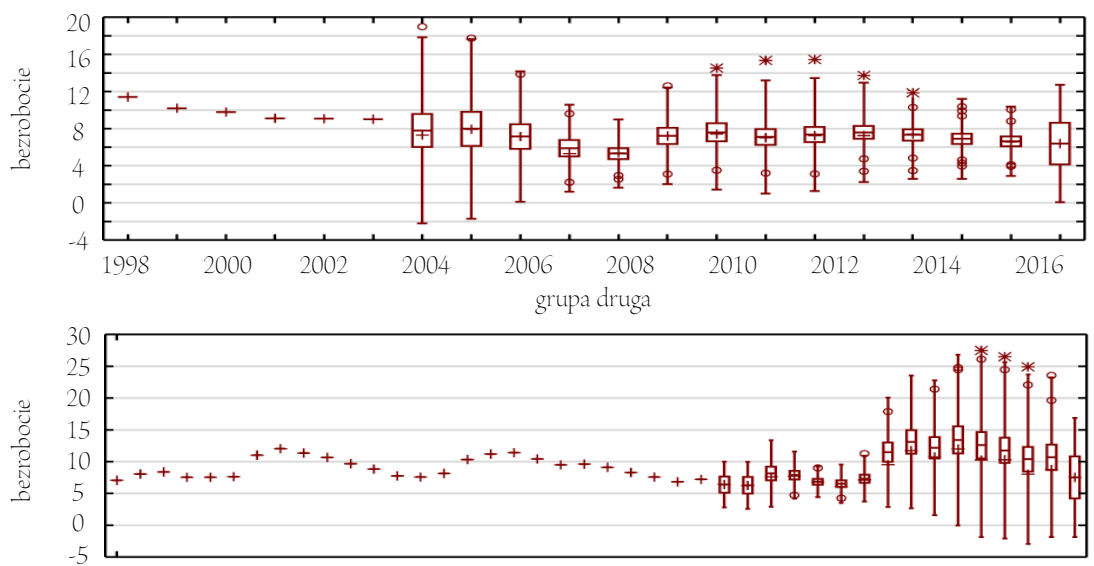

197619781980198219841986198819901992199419961998200020022004200620082010201220142016

- średnia $\mathbf{\square}$ średnia \pm błąd standardowy $\mathbf{I}$ średnia $\pm 2 *$ odylenie standardowe $\mathbf{O}$ odstające $*$ ekstremalne + mediana

Źródło: Opracowanie własne na podstawie World Bank (2019). 
Wykres 9.

Poziom transferów względem nierówności społecznych w dwóch grupach państw

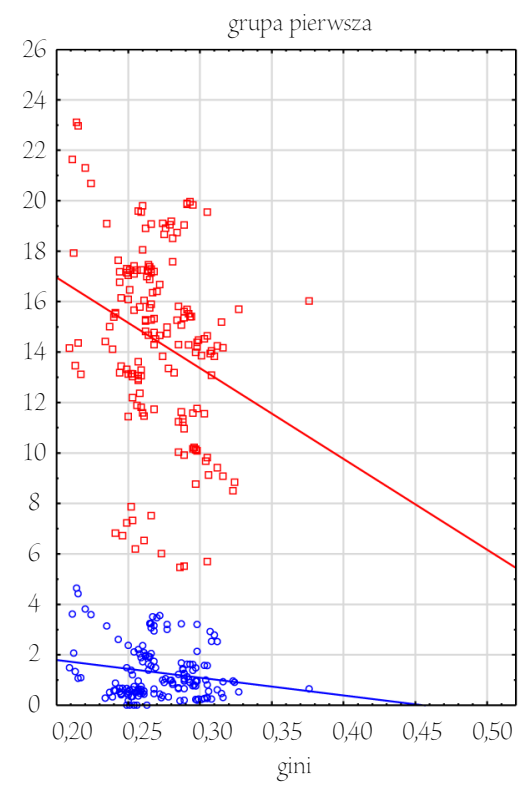

- wydatki socjalne na bezrobotnych (w \% PKB)

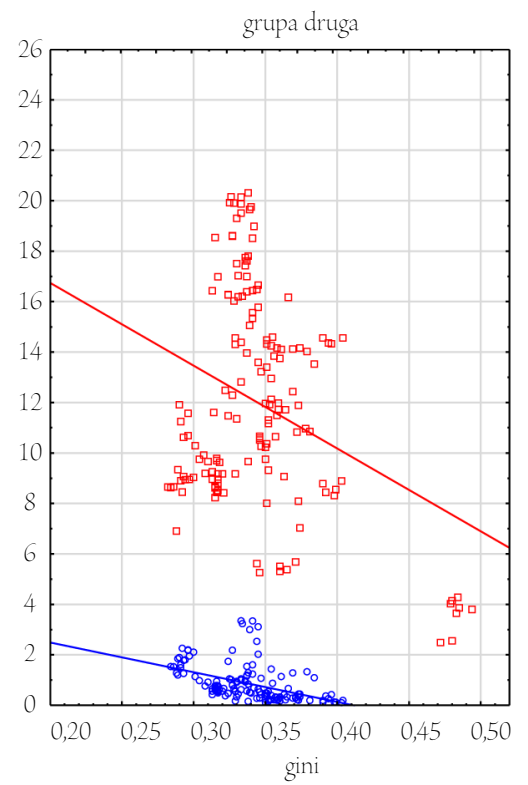

- wydatki socjalne na gospodarstwa domowe (w \% PKB)

Źródło: Opracowanie własne na podstawie World Bank (2019). 


\title{
Wykres 10.
}

Konsumpcja alkoholu (11 per capita) oraz udział palaczy (\% społeczeństwa) w analizowanych państwach
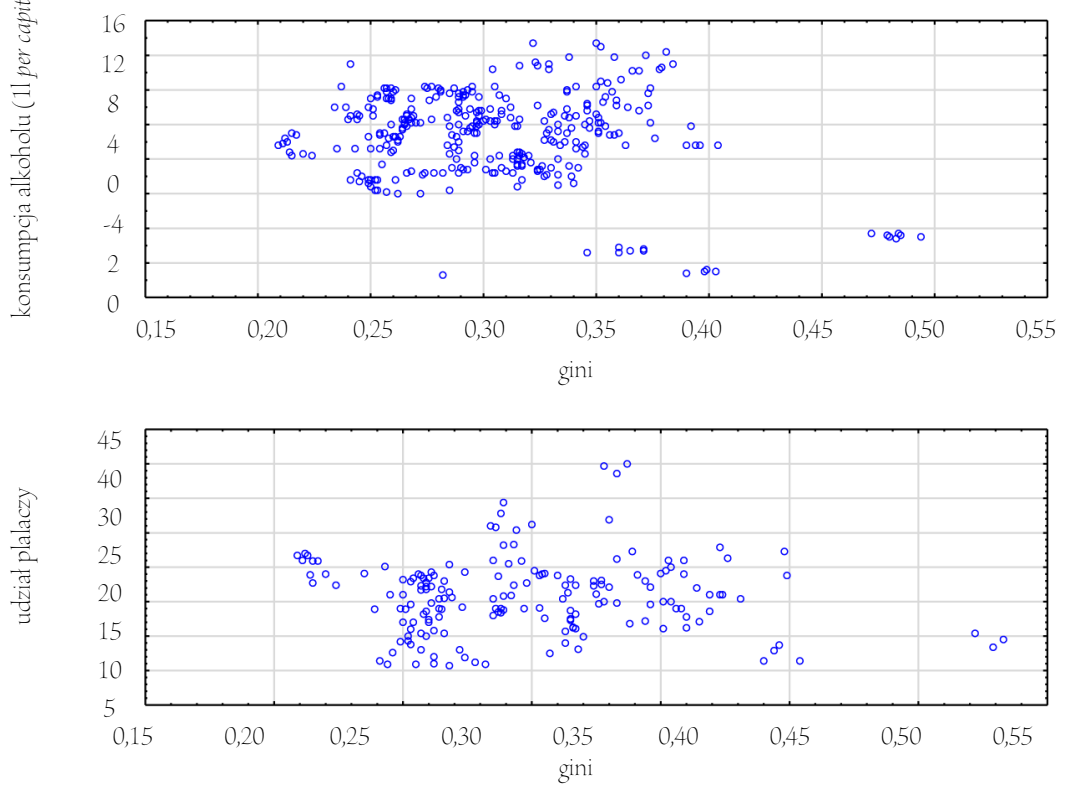

Źródło: Opracowanie własne na podstawie World Bank (2019).

Community inequalities: features of societies with high income differentiation

\begin{abstract}
Motivation: The issue of income inequality is now at the center of public debate. In re-cent years, the phenomenon of income disproportions can be noticed, although not in all countries. Its consequence is the deteriorating social condition, understood as socially undesirable behavior.

Aim: The aim of this study was to identify the features that appear with increasing in-come inequality in society. Materials and methods: Data from various sources was used: the Organization for Economic Co-operation and Development (OECD), the World Bank and the World Health Organization (WHO). The time range covers the years 1960-2017. The descriptive method as well as selected quantitative methods were used: the correlation index, the Warda dendrogram method and spectral analysis, used to assess the cyclicality of economic phenomena.

Results: On the basis of the conducted analysis, it is possible to notice the increased and more unstable level of unemployment in countries with higher income disparities.
\end{abstract}

Keywords: income inequalities; unemployment; poverty JEL: D63; D69 
